\title{
Forest nutrition and fertilization in teak (Tectona grandis L.f.) plantations in Central America ${ }^{\dagger}$
}

\author{
Jesús Fernández-Moya ${ }^{1,2^{*}}$, Alfredo Alvarado², Alfonso San Miguel-Ayanz ${ }^{1}$, Miguel Marchamalo-Sacristán ${ }^{3}$ \\ From Third International Congress on Planted Forests \\ Bordeaux, France; Dublin, Ireland; and Porto and Estoril, Portugal. 16-21 May 2013
}

\begin{abstract}
Background: Soil fertility management and forest nutrition are key factors determining management and productivity of both natural and planted forests. Reference values for foliar and soil nutrient contents and assessment of nutrient balances to evaluate the sustainability of planted forest systems can guide forest managers in determining whether or not additional fertilisation is required.
\end{abstract}

Methods: This review summarises the authors' research into the nutritional requirements for planted teak (Tectona grandis L.f.) forests in Central and South America. Teak is an important species for commercial forest plantations, usually in carefully selected productive sites, with rotations of 20-25 years and commercial volume anticipated to be around $10 \mathrm{~m}^{3} \mathrm{ha}^{-1}$ year ${ }^{-1}$.

Results: Foliar nutrient concentration values can be used as a reference to evaluate the nutritional status of planted teak forests. In addition, there may be an association between the dynamics of the concentrations of $\mathrm{K}$, $\mathrm{Mg}$ and $\mathrm{N}$ with tree age and the age-related declines in teak productivity. Timber extraction by felling constitutes a major nutrient output from the system and repeated nutrient exports during several rotations could be a cause of soil nutrients depletion, especially P and K which typically have low availability in these Central American systems. Multivariate analyses have been shown to be appropriate and helpful tools for grouping forest stands by fertility classes (i.e. soil management zones using the terminology of precision agriculture).

Conclusions: The techniques developed can be used as tools for the design of efficient fertilisation programmes, taking into account the inherent heterogeneity of soil fertility across different stands. This is considered as a first step towards a precision forestry scheme. Whether age-related changes in nutrient concentrations are a cause or a consequence of age-related declines in productivity is an important issue for future research.

\section{Introduction}

Soil management and forest nutrition are key factors determining management and productivity of both natural and planted forests. Furthermore, soil nutrient availability is the only environmental factor that can be modified in a practical way by forest managers. Other factors, such as radiation, temperature and water, are very expensive or impossible to manipulate in a specific location (Binkley 1986). Hence, fertilisation programmes are necessary and should complement other silvicultural

\footnotetext{
* Correspondence: jesusfmoya@gmail.com

'Dpto. Silvopascicultura. E.T.S.I. Montes. Technical University of Madrid (UPM).

Ciudad Universitaria s/n. 28040 Madrid. Spain

Full list of author information is available at the end of the article
}

plans in order to achieve both productivity and sustainability of planted forests. Despite the relevance of forest nutrition in planted forests, there was little focus on this topic at the $3^{\text {rd }}$ Congress on Planted Forests in Europe in 2013 although shortages of forest soil scientists and forest nutrition experts was recognised in some discussion groups of the Congress as a relevant matter of concern. These issues will make it difficult to achieve the productivity rates from planted forests that are desired by many investors.

Teak (Tectona grandis L.f.) has been planted extensively in Central America, acquiring socio-economical relevance due to its productivity (e.g. Pandey and Brown 2000; De Camino et al. 2002; Kollert and Cherubini 
2012). The present paper summarises some of the authors' research to produce preliminary nutritional guidelines for teak plantations in Central and South America. More detail on individual studies cited can be obtained from the original papers. Nutrition and management of other regionally important species such as Terminalia amazonia (J.F.Gmel.) Exell, Cedrela odorata L., Vochysia sp. and Alnus acuminata Kunth. are also being studied within the current programme of research but are outside the scope of this paper.

\section{Current situation of teak plantations in Central America}

Teak is a species of tropical hardwood that is important economically and socially (e.g. Pandey and Brown 2000). It is widely planted in tropical regions (total planted area of $4.3 \times 10^{6}$ ha world-wide), which represents $1.5-2 \%$ of the global cover of planted forests (Food and Agriculture Organization 2010; Kollert and Cherubini 2012). Teak plantations have been widely established in Central America, initially in Costa Rica and Panama (De Camino et al. 2002) and more recently in Guatemala, Mexico, El Salvador and Nicaragua. The current area of teak plantations in Central America is estimated to be 132,780 ha, of which 55,000 ha are in Panama and 31,500 ha in Costa Rica (Kollert and Cherubini 2012). Even though Central America represents only 3\% of the worldwide coverage of teak plantations, the species is considered very important in the region and covers a large proportion of Central American forest land (Kollert and Cherubini 2012). The situation in South America is somewhat different. The area of teak plantations has increased significantly in Brazil and Ecuador, with 65,000 ha and 45,000 ha respectively in 2010, compared to the 1,000 ha planted in Ecuador in 1995, when there was no teak plantation reported in Brazil (Kollert and Cherubini 2012). However, the large size of these countries makes teak plantations a less important land use compared with its relevance in Central America (Kollert and Cherubini 2012). This lesser importance may change in the near future as an increasing tendency to plant teak forests is expected in the short term in South America, especially with large afforestation projects in Ecuador, Colombia and Venezuela. Teak plantations are established at two different scales in both Central and South America, either large company investments or small-scale plantations by individual farmers. The wide range of soil and climatic environments in Central America and a variety of management regimes all influence the average productivity of teak plantations, which result in highly variable yields, ranging from 5 to $30 \mathrm{~m}^{3} \mathrm{ha}^{-1} \mathrm{yr}^{-1}$ in rotations of between 6 and 30 years (Kollert and Cherubini 2012).

\section{Nutrient concentration dynamics in teak plantations}

Nutrient concentration age dynamics of teak plantations in Central America are discussed in depth in FernándezMoya et al. (2013). In that work, a chronosequence approach was used to analyse nutrient concentrations in foliage, bark, wood and branches in teak plantations aged from 1 to 19 years old. A total of 28 stands, covering three regions in Costa Rica (Guanacaste and Northern lowlands) and Panama (Canal Watershed) were used for that purpose (Figure 1). The climate of all these three regions is classified as tropical wet forest according to Holdridge's life zones (Holdridge 1967), with similar mean annual rainfall (2,500-3,100 mm), although in Guanacaste the dry season is slightly longer than at the two other sites. The soils of the study areas are also similar (Table 1), although the soil in northern region of Costa Rica is slightly less fertile than the other sites and it is more acidic (Fernández-Moya et al. 2013).

Briefly, Fernández-Moya et al. (2013) found a tendency for the concentration of nitrogen $(\mathrm{N})$ to decrease with age in all tissues, which supported previous results reported for teak (Montero 1999). In addition, foliar potassium $(\mathrm{K})$ concentration remained constant with tree age but decreased in all the other tissues. Foliar magnesium $(\mathrm{Mg})$ concentration increased with tree age, also reported by Montero (1999), while it decreased in boles and branches. The importance of each of these trends was reviewed in Fernández-Moya et al. (2013), but it is noticeable that all of them are considered to be potentially related with the age-related declines in forest productivity (Gower et al. 1996; Gholz and Lima 1997; Ryan et al. 1997; Binkley et al. 2002; Barker and Pilbeam 2006). Decreases in $N$ concentration with tree age are considered to be either a cause or a consequence of the decline in productivity associated with increasing tree age. Potassium has an important regulatory effect on stomatal movement and transpiration rates. Thus, foliar $K$ requirements would be expected to increase with tree age because: they modify transpiration rates; control increased hydraulic resistance; and sustain a higher photosynthesis rate, which are all key physiological mechanisms related to the age-related decline in plant productivity. Foliar Mg may increase with age to meet the physiological demands of older trees. These physiological needs include the following: (a) sustaining high photosynthesis efficiency; (b) partially inhibiting excess photophosphorylation; and (c) regulating leaf stomatal conductance. Hence, the decrease in the concentration of $\mathrm{N}, \mathrm{K}$ and $\mathrm{Mg}$ in branches and boles (and bark in the case of $\mathrm{N}$ and $\mathrm{K}$ ) could be explained as a retranslocation process aiming to maintain or fulfil greater foliar requirements of those elements in older plantations. 


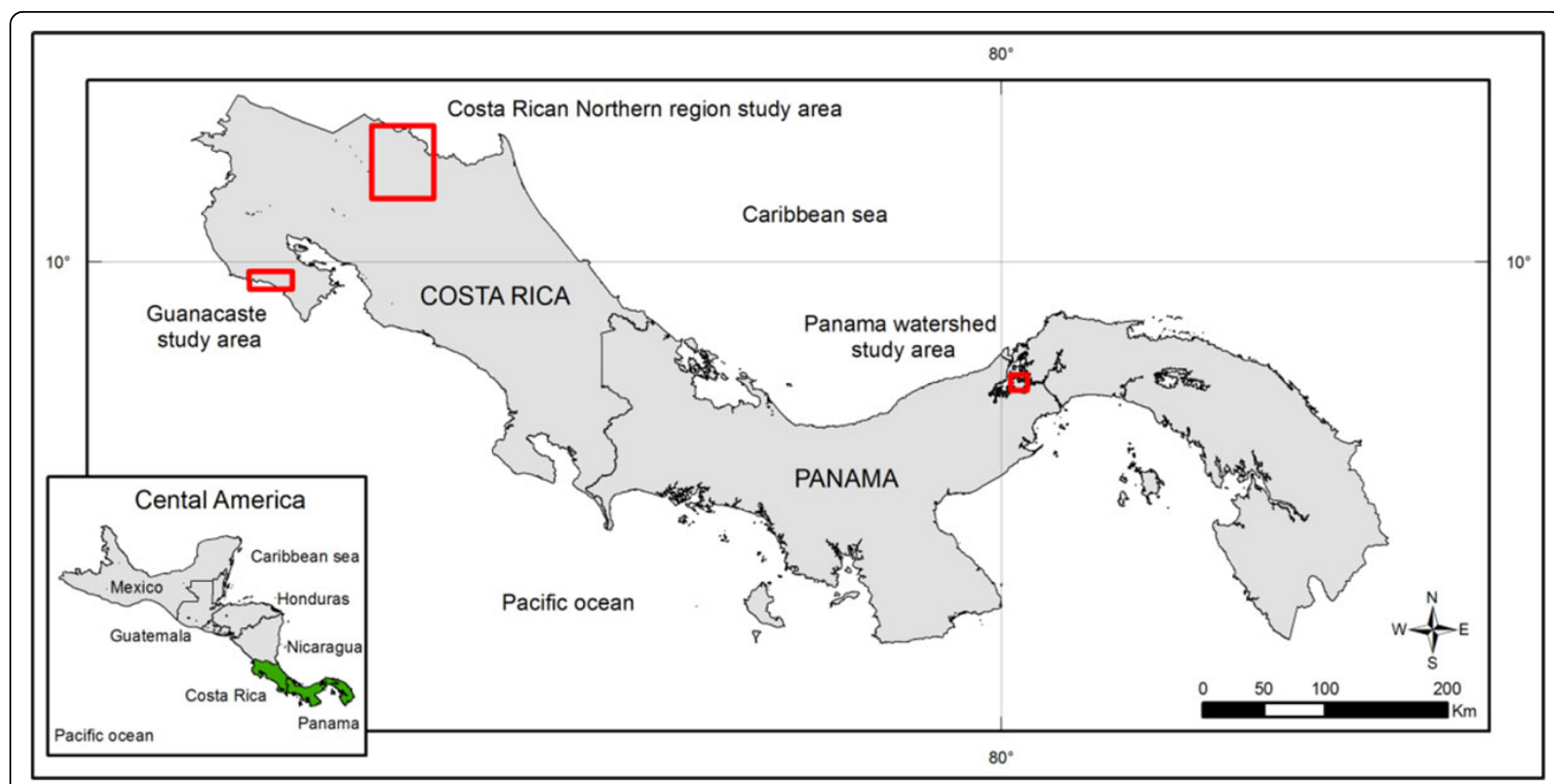

Figure 1 Location of the three teak (Tectona grandis L.f.) plantations analysed in Fernández-Moya et al. (2013): Guanacaste (Costa Rica); northern region (Costa Rica) and Panama Canal Watershed (Panama).

Relatively high micronutrient concentrations are also required to maintain an optimum nutritional status in teak plantations (Fernández-Moya et al. 2013), although this has not been reported in other similar studies
(Nwoboshi 1984; Totey 1992; Negi et al. 1995; Kumar et al. 2009). Some micronutrients, such as zinc (Zn), copper $(\mathrm{Cu})$, and molybdenum $(\mathrm{Mo})$, are generally deficient in highly weathered tropical soils (Barker and Pilbeam 2006);

Table 1 Summary of topsoil $(0-20 \mathrm{~cm}$ depth) properties at the different study areas; means and coefficients of variation (in parentheses) are provided.

\begin{tabular}{|c|c|c|c|c|c|}
\hline & $\begin{array}{c}\text { Northern region, } \\
\text { Costa Rica } \\
(\mathrm{n}=11)\end{array}$ & $\begin{array}{c}\text { Guanacaste, } \\
\text { Costa Rica } \\
(n=9)\end{array}$ & $\begin{array}{c}\text { Canal Zone, } \\
\text { Panama } \\
(n=3)\end{array}$ & $\begin{array}{l}\text { TOTAL } \\
(\mathrm{n}=23)\end{array}$ & $\begin{array}{l}\text { TOTAL** } \\
\left(\mathrm{kg} \mathrm{ha}^{-1}\right)\end{array}$ \\
\hline $\mathrm{pH}$ & $5.11 \quad(6)$ & $5.90 \quad(6)$ & $6.70 \quad(12)$ & $5.63 \quad(12)$ & \\
\hline Acidity $\left(\mathrm{cmol}(+) \mathrm{L}^{-1}\right)$ & $\mathbf{0 . 7 0 *}(5)$ & $0.31 \quad(30)$ & 0.15 & $0.48 \quad(81)$ & \\
\hline $\mathrm{Ca}\left(\mathrm{cmol}(+) \mathrm{L}^{-1}\right)$ & $4.45 \quad(44)$ & 21.36 & 20.97 & $13.22(74)$ & 5288 \\
\hline $\mathrm{Mg}\left(\mathrm{cmol}(+) \mathrm{L}^{-1}\right)$ & $1.46 \quad(47)$ & $6.89 \quad(54)$ & $5.25 \quad(64)$ & $4.08 \quad(89)$ & 1142 \\
\hline $\mathrm{K}\left(\mathrm{cmol}(+) \mathrm{L}^{-1}\right)$ & $\mathbf{0 . 1 3}$ * (109) & $0.33 \quad(87)$ & $0.36 \quad(82)$ & $0.24 \quad(101)$ & 187 \\
\hline $\operatorname{ECEC}^{\mathrm{a}}\left(\mathrm{cmol}(+) \mathrm{L}^{-1}\right)$ & $6.74 \quad(31)$ & $28.90 \quad(32)$ & $26.72(40)$ & 18.02 (71) & \\
\hline $\mathrm{AS}^{\mathrm{b}}(\%)$ & $11.96 *$ & $1.22 \quad(58)$ & $0.65 \quad(55)$ & 6.28* (139) & \\
\hline$P\left(m g L^{-1}\right)$ & $3^{*} \quad(114)$ & $3 * \quad(146)$ & $2^{*}(0)$ & $3^{*} \quad(124)$ & 6 \\
\hline $\mathrm{Zn}\left(\mathrm{mg} \mathrm{L}^{-1}\right)$ & $2 *(84)$ & $3(58)$ & $3(107)$ & $\mathbf{2}^{*}(77)$ & 4 \\
\hline $\mathrm{Cu}\left(\mathrm{mg} \mathrm{L}^{-1}\right)$ & $8 \quad(19)$ & 11 (85) & 4 (83) & $9(71)$ & 18 \\
\hline $\mathrm{Fe}\left(\mathrm{mg} \mathrm{L}^{-1}\right)$ & 165 & 37 (81) & 65 (154) & $102(75)$ & 204 \\
\hline$M n\left(m g L^{-1}\right)$ & $43 \quad(171)$ & 38 (82) & $19(101)$ & $38 \quad(142)$ & 76 \\
\hline Organic matter (\%) & $4.6 \quad(27)$ & 3.8 (28) & 4.6 (16) & $4.3 \quad(27)$ & \\
\hline Sand (\%) & 24.9 (23) & $23.4 \quad(56)$ & 29.0 & $24.8 \quad(38)$ & \\
\hline Silt (\%) & $18.4 \quad(13)$ & $36.9(42)$ & 36.8 (43) & 28.0 & \\
\hline Clay (\%) & $56.7(11)$ & $39.7 \quad(22)$ & $34.3(50)$ & $47.1 \quad(27)$ & \\
\hline
\end{tabular}

More details can be found in Fernández-Moya et al. (2013).

a ECEC: effective cation exchange capacity.

b AS: acidity saturation.

* = Values outside the adequate reference soil levels (Bertsch 1998).

** = Estimation of the topsoil availability in $\mathrm{kg}$ ha- 1 to be compared with nutrient extraction by final felling (Table 3) 
while boron (B) is commonly deficient in soils throughout the world (Lehto et al. 2010). The results of FernándezMoya et al. (2013) show that particular care should be taken to evaluate the B and $\mathrm{Zn}$ status in teak planted forests throughout the tropics.

To address forest managers' needs, a preliminary reference guide (Table 2) has been produced that indicates the levels of foliar nutrient concentrations for are considered adequate for teak plantations in Central America. This guide was generated using results from statistical modelling of key parameters (Fernández-Moya et al. 2013). These models estimated the concentrations of nutrients in several tree tissues (foliage, bark, wood and branches) depending on tree age, and are based on representative teak plantations where the nutritional status is considered as adequate. Foliar concentrations are considered key parameters for evaluating the nutritional status of a stand because they: (a) are highly dependent on site and soil parameters; (b) reflect the current nutrient supply; (c) allow diagnosis of nutritional deficiencies when they are not severe enough to cause visually observable symptoms and, thus, allow action to be taken before the effects on productivity are significant; and (d) deficiency symptoms are easily confused with other effects when visual guidelines alone are used (Mead 1984; Drechsel and Zech 1991). The utility of the reported guide (Table 2) comes from its simplicity as it is designed as a management reference for a range of plantations regimes and ages. The guide is used as follows: (1) perform a foliar

Table 2 Estimation of adequate values for foliar nutrient concentration by age in teak (Tectona grandis L.f.) plantations in Costa Rica and Panama based on the models proposed in Fernández-Moya et al. (2013). Macronutrient concentrations ( $\mathrm{N}, \mathrm{Ca}, \mathrm{K}, \mathrm{Mg}, \mathrm{P}$ and $\mathrm{S})$ are expressed as percentages, while micronutrient concentrations ( $\mathrm{Fe}, \mathrm{Mn}, \mathrm{Cu}, \mathrm{Zn}$ and $\mathrm{B}$ ) are expressed in $\mathrm{mg} \mathrm{kg}^{-1}$. Confidence intervals $(\alpha=0.05)$ are reported in parentheses.

\begin{tabular}{cccc}
\hline & \multicolumn{3}{c}{ Adequate ranges of foliar nutrient concentration } \\
\cline { 2 - 4 } & $\mathbf{5}$ years & 10 years & 19 years \\
\hline $\mathrm{N}$ & $2.13(1.97,2.33)$ & $1.97(1.83,2.15)$ & $1.76(1.64,1.91)$ \\
$\mathrm{Ca}$ & & $1.34(1.13,1.54)^{*}$ & \\
$\mathrm{~K}$ & & $0.88(0.73,1.02)^{*}$ & \\
$\mathrm{Mg}$ & $0.26(0.18,0.31)$ & $0.29(0.22,0.34)$ & $0.34(0.27,0.39)$ \\
$\mathrm{P}$ & & $0.16(0.12,0.20)^{*}$ & \\
$\mathrm{~S}$ & & $0.12(0.11,0.13)^{*}$ & \\
$\mathrm{Fe}$ & $129.61(84.63,174.59)^{*}$ & \\
$\mathrm{Mn}$ & $42.55(39.03,46.07)^{*}$ & \\
$\mathrm{Cu}$ & $11.08(10.22,11.93)^{*}$ & \\
$\mathrm{Zn}$ & $32.00(24.74,39.26)^{*}$ & \\
$\mathrm{~B}$ & & $19.62(18.32,20.91)^{*}$ & \\
\hline
\end{tabular}

* When no significant correlation was found between foliage nutrient concentration across tree age, values are given only for 10-year-old trees. collection and analysis of the samples; and (2) compare the values obtained with the baseline references from the guide. If the empirical value is within the range given in the guide then nutrition is considered adequate. However, if a nutrient concentration is below or above the range given in the guide then professional advice should be sought or a more detailed study of the specific site and soil conditions should be undertaken to help explain differences observed.

\section{Sustainability and nutrient balance in teak plantations}

Some forest managers and researchers have traditionally argued that the quantities of nutrients taken up by a growing forest and then removed from site during timber extraction need to be assessed (Rennie 1955; Binkley 1986; Worrel and Hampson 1997). However, Fölster and Khanna (1997) pointed out a traditional lack of concern of this problem in planted forests. This is at least partially demonstrated by the shortage of representation of this topic at the abovementioned $3^{\text {rd }}$ Congress of Planted Forests in 2013. Agronomists have traditionally analysed when, where, and at what rates nutrients are accumulated by plants (and extracted as agricultural products) in order to manage nutrients in an efficient and environmentally acceptable manner (e.g. Sadler and Karlen 1995; Bertsch 1998). These studies have been referred to as "nutrient absorption curves" (curvas de absorción in Spanish) or "nutrient accumulation dynamics with age" (Alvarado 2012a). In order to provide information for the nearmaximum accumulation rates of any given crop, nutrient absorption studies are carried out in sites where a nearmaximum yield of the crop is achieved (e.g. Sadler and Karlen 1995; Bertsch 1998). The maximum requirements for a species can be assessed by analysing nutrient accumulation in the most productive sites, which are assumed to have no nutrient deficiencies, and also in dominant or co-dominant trees across such sites. Nutrient accumulation dynamics of a species can be used to estimate the: (i) nutrient removal by thinning or harvesting; (ii) nutrient requirements of the species during one rotation; (iii) amount of nutrients left at a site after harvesting, which will be recycled and reused during the next rotation; and (iv) minimum nutrient inputs (fertilisers) the system need to be sustainably managed (Bertsch 1998; Alvarado 2012a).

The biomass of tree components (foliage, bark, wood and branches) was also measured, and nutrient accumulation in tree biomass was estimated by multiplying nutrient concentration by biomass (Fernández-Moya, Murillo et al. 2014) as part of the same study described in FernándezMoya et al. (2013). The amounts of nutrients accumulated by a stand of 150 trees ha $^{-1}$ at age 19 are given in Table 3 . The accumulation of $K$ and $P$ in tree biomass was 
Table 3 Mean nutrient contents for three 19-year-old teak stands of 150 trees ha ${ }^{-1}$ in Costa Rica and Panama (from Fernández-Moya, Murillo et al. 2014)

\begin{tabular}{ccc}
\hline Nutrient & \multicolumn{2}{c}{ Amount of nutrient $\left(\mathbf{k g ~ h a ~}^{\mathbf{- 1}}\right)$} \\
\cline { 2 - 3 } & Accumulated & Exported through bole and bark \\
\hline $\mathrm{N}$ & 405 & 220 \\
$\mathrm{Ca}$ & 661 & 281 \\
$\mathrm{~K}$ & 182 & 88 \\
$\mathrm{Mg}$ & 111 & 63 \\
$\mathrm{P}$ & 33 & 23 \\
$\mathrm{~S}$ & 53 & 39 \\
$\mathrm{Fe}$ & 9 & 6 \\
$\mathrm{Mn}$ & 0.47 & 0.13 \\
$\mathrm{Cu}$ & 0.22 & 0.11 \\
$\mathrm{Zn}$ & 0.92 & 0.21 \\
$\mathrm{~B}$ & 1 & 0.40 \\
\hline
\end{tabular}

relatively high (Fernández-Moya, Murillo et al. 2014) in contrast with the low values of soil-available $\mathrm{K}$ and P found at the same three sites (Table 1) (Bertsch 1998; Fernández-Moya et al. 2013).

Timber extraction by final felling constitutes a major nutrient output from the system. The amount of nutrients accumulated in wood and bark at 19 years old is considered as an approximation of what is extracted in the final harvesting at the end of the rotation. Based on the models proposed by Fernández-Moya, Murillo et al. (2014), harvesting (bole and bark) of teak at age 19 from a stand with 150 trees ha ${ }^{-1}$ would remove nutrients as shown in Table 3. Hence, nutrient export by timber extraction at the end of the rotation represents approximately half of the estimated nutrient accumulation of mature stands, varying between 23 and 73\%, depending on the element. Clearly, removing large amounts of nutrients through timber harvesting over several rotations could cause of nutrient depletion and soil degradation, and consequently cause a decrease in forest productivity. This scenario has also been reported by other authors (e.g. Rennie 1955; Miller 1984; Fölster and Khanna 1997; Worrel and Hampson 1997; Evans and Turnbull 2004; Evans 2009). Although the Forest Stewardship Council (FSC) (2004) and several other authors (e.g. Rennie 1955; Worrel and Hampson 1997) recommend fertiliser application to sustain short-cycle plantation productivity, the need to evaluate the sustainability of the plantations in terms of nutrient cycling is still a voluntary requirement and perhaps this is a major shortfall in some socio-political instruments such as these certification schemes.

The models proposed in Fernández-Moya, Murillo et al. (2014) allow managers to calculate the amount of nutrients accumulated in bole and bark tree biomass depending on tree age. Hence, these models can be used to estimate the nutrient extraction in different thinning management scenarios. Estimated nutrient export (accumulated at bole and bark) by teak thinning or final felling could provide a reference for the minimum nutrient inputs the managers should add in via fertilisation and at what stages throughout a rotation period, depending on the site's soil and nutrient environmental inputs and outputs, thinning regimen and other silvicultural variables. Nutrient cycling in planted teak forests should be analysed in more detail in order to evaluate the sustainability of the system. Only removal of nutrients through timber extraction is analyzed, but many other causes of nutrient decline are possible including poor site preparation techniques (e.g. burning and scarification), leaching of nutrients prior to crown closure and immobilisation of nutrients in a developing litter layer in mature plantations. Fernández-Moya, Murillo et al. (2014) serves as a first step and general approach to the subject in Central America and reflects the need to properly analyse not only the direct output via timber harvest (including the output via thinning) but also the complete input and output factors which would allow the nutrient balance for the system to be more accurately analysed.

\section{Fertilisation practices in planted teak forests}

Despite the international relevance of teak plantations, only few fertilisation studies of planted teak forests have been published (Kumar 2011). However, fertiliser application is a common practice in teak plantations. Fertiliser application generally occurs at establishment only in Central America while it continues to intermediate ages. in Asia The results of fertilisation trials in Latin America (reviewed by Alvarado 2012b) and Asia and Africa (reviewed by Kumar 2011) are inconsistent: some of them show a positive effect while some other do not find any noticeable effect. The response of forests to fertiliser is known to vary according to a wide range of factors, and can be highly site specific. Hence, more research is needed to understand the underlying differences between various fertilisation trials in order to be able to predict the fertilisation response before the application of fertilisers, with the consequent economic and environmental benefits (Montes et al. 2012). Despite this lack of consistency in the effect of fertilisation trials in teak plantations, fertiliser application is usually recommended and generally undertaken. Some examples of fertiliser prescriptions published for teak plantations are as follows:

- Young plantations in Kerala (Southern India) typically receive $163 \mathrm{~kg} \mathrm{ha}^{-1}$ urea, $375 \mathrm{~kg} \mathrm{ha}^{-1}$ mussoorie rock phosphate, $145 \mathrm{~kg} \mathrm{ha}^{-1}$ muriate of potah, 105 $\mathrm{kg} \mathrm{ha}^{-1}$ quick lime and $373 \mathrm{~kg} \mathrm{ha}^{-1} \mathrm{Mg}$ sulphate from two split applications in the first year and four split applications during the second and third years (Balagopalan et al. 2000, cited in Kumar 2011). 
- Young and intermediate plantations in Kerala (Southern India) typically receive 30-40 g plant ${ }^{-1} \mathrm{~N}$, 15-20 g plant $^{-1} \mathrm{P}_{2} \mathrm{O}_{5}$, and 15-20 g plant $^{-1} \mathrm{~K}_{2} \mathrm{O}$ per year during the first 2 to 5 years and thereafter once every 3 to 4 years up to 10 to 12 years (KAU 200, cited in Kumar 2011).

- Young and intermediate plantations in Costa Rica (and Central America) follow a general recommendation of a N-P-K formula with a ratio of 10-30-10 or 12-24-12 at the beginning of the rainy season and an extra $\mathrm{N}$ dose during the maximum rain period until the canopy closes at 3 to 4 years old (Alvarado $2012 \mathrm{~b})$. In practice, it usually consists in 50-150 g per plant of an N-P-K product at establishment.

\section{First steps for precision forestry across planted teak forests: using multivariate analysis for grouping stands into soil fertility management zones}

Soil heterogeneity is one of the major drivers of precision agriculture. One of the basic principles of precision agriculture is to modify fertiliser application (formulae and dosage) depending on localised variations in soil properties and plant requirements. Thus, management occurs at an individual-field level rather than considering each farm as a whole (Robert 2002). Such precision farming can be established based on: (i) site-specific management; or (ii) management zones (Robert 2002). Site-specific management is designed to operate on a small scale and it is usually focused upon soil-type heterogeneity within each field, assuming microclimate homogeneity. A major barrier for site-specific management is the economic cost of generating a satisfactory soil map. Management zones consist of treatments specified at a larger scale, across groups of sites, for cases when budgetary or other restrictions limit the scope for a broader range of management treatments (Robert 2002). In a forestry context, site-specific management would be stand specific while management zones would be groups of stands. Fox (2000) was one of the first researchers to link precision agriculture and precision forestry by assessing that "site-specific management is the key to sustaining soil quality and long-term site productivity" for intensively managed forest plantations. However, any changes recommended to forest management derived from soil heterogeneity may be not easily applied across a detailed scale operation. Forest management is usually less intensive than agriculture, and little consideration is given to forest nutrition and soil management in many occasions. Hence, establishing stand-specific nutritional plans would be very complicated in many forests at present. On the other hand, in many large-scale intensively managed planted forests, stands can be grouped by similarity in their soil fertility, through which managers could delineate nutritional management areas, and therefore facilitate more efficient and productive management. Classifying forest stands into groups with similar soil properties (i.e. organising stands into management zones) readily facilitates identification of a limited number of nutritional management groups. Delineation of intra-field management zones, i.e. zones of uniform management have been assessed as an important initial stage in the implementation of site-specific nutrient management (Ortega and Santibáñez 2007).

Fernández-Moya, Alvarado et al. (2014) examined how effectively multivariate analysis techniques can contribute to decision making. Through their use as a tool for analysing soil fertility databases, these techniques can classify stands by soil fertility, and thereby be helpful for the design of more efficient fertilisation programmes for planted forests. In that paper, an example was provided of how these analyses can be performed. Data from a specific planted forest in Costa Rica (approximately 2,500 ha of teak plantations owned by Panamerican Woods Ltd) was divided into two main farms (Carrillo and Palo Arco) on the North Pacific Coastal Range of Costa Rica (Figure 2).

Several multivariate analysis techniques were employed as alternative options for simplifying the data: Principal Component Analysis (PCA); Non Metric Multidimensional Scaling (NMDS) and Cluster Analysis. These different methodologies were tested using the data from the 195 samples of the topsoil database assembled by the company. Each sample comprised of data for the following variables: $\mathrm{pH}$; exchangeable $\mathrm{Ca}$; $\mathrm{Mg}$; K; acidity; P; Cu; Fe; $\mathrm{Mn}$ and $\mathrm{Zn}$; Effective Cation Exchange Capacity (ECEC); acidity saturation; Ca saturation; Mg saturation and $\mathrm{K}$ saturation. More details about the methodology can be found in FernándezMoya, Alvarado et al. (2014).

The delineation of six different groups of stands with similar soil fertility by cluster analysis resulted in an increase of the homogeneity of soil fertility attributes in each group. This grouping enabled a more detailed examination of soil fertility in the planted forests to be performed. As a consequence of grouping the soil samples, some nutrient deficiencies were discovered, which would have otherwise been hidden if the regular approach had been used to analyse the data (Fernández-Moya, Alvarado et al. 2014).

\section{Final considerations}

The authors' current research programme has included the establishment of several fertilisation trials in planted teak forests in Central America during recent years but it is too early to draw any conclusions from the set. 


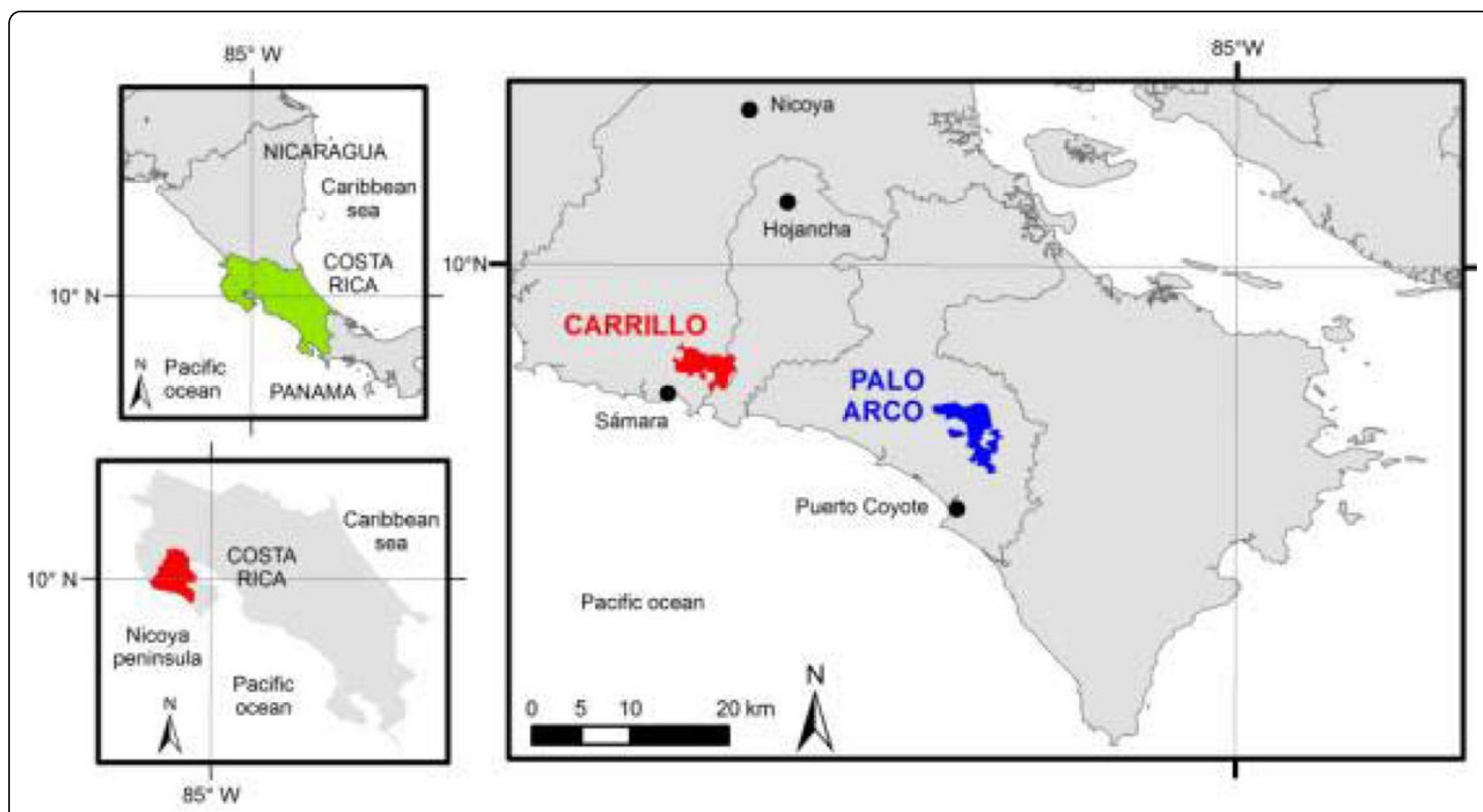

Figure 2 Location of the two study sites on the north Pacific coast of Costa Rica (Nicoya Peninsula), comprising two teak (Tectona grandis L.f.) plantations owned by Panamerican Woods Ltd., at Carrillo and Palo Arco (Fernández-Moya, Alvarado et al. 2014).

Soil studies have been intensively used in Central America for evaluating and selecting sites to establish new planted forests. Nowadays, new tools are being developed for this type of analysis, such as statistical approaches and remote sensing. Different regression techniques are being used to build models, which would be able to predict Site Index based on soil and climate at a specific site. In addition, digital soil mapping and modelling techniques (e.g. McBratney et al. 2000) are being explored for predicting the preliminary suitability for teak plantations, in combination with some previous point observations and some broad-scale variables, such as those derived from Landsat images, Digital Elevation Models (DEM) and their derivatives. More research is needed into this subject, while also taking into account climate and soil in order to predict the response of the trees to fertilisation.

Our research contributes to greater opportunities for forest managers to understand the relative foliar nutritional status of sites in across Central and South America. It also advocates investigation of nutrient balance based on nutrient accumulations in biomass materials both exported and those retained on site. Our interest in nutrition is encouraged by the development of new techniques and remote sensing tools and overall we believe through time our ability to model nutritional indices and maintain sustainability shall be improved with ongoing focus in these areas.

\section{Competing interests}

The authors declare that they have no competing interests.

\section{Authors' contributions}

JFM wrote the paper summarizing the results published by the research group in the last years. AA, ASMA and MMS are co-authors in most of these cited publications. All authors read and approved the final manuscript.

\section{Acknowledgements}

The authors would like to acknowledge the personnel of the Natural Resources Laboratory at CIA (UCR) for their help and assistance about the contents of this paper. The authors also thank to two anonymous reviewers for their very helpful comments to the present manuscript.

\section{Declaration}

Publication of this supplement was funded by the New Zealand Forest Research Institute Limited (trading as Scion).

This article has been published as part of JOURNAL Volume 44 Supplement 1, 2014: Proceedings of the Third International Congress on Planted Forests. The full contents of the supplement are available online at http://www. nzfforestryscience.com/supplements/44/S1.

\section{Authors' details}

${ }^{1}$ Dpto. Silvopascicultura. E.T.S.I. Montes. Technical University of Madrid (UPM). Ciudad Universitaria s/n. 28040 Madrid. Spain. ${ }^{2}$ Centro de Investigaciones Agronómicas, Universidad de Costa Rica (CIA-UCR). Costa Rica. ${ }^{3}$ Dpto. Ingeniería y Morfología del Terreno. E.T.S.I. Caminos, Canales y Puertos. Technical University of Madrid (UPM). Ciudad Universitaria s/n. 28040 Madrid. Spain.

Published: 26 November 2014

\section{References}

Alvarado A: Diagnóstico de la nutrición en plantaciones forestales. In Nutrición y fertilización forestal en regiones tropicales A Alvarado \& J Raigosa 2012a, 93-120, San José, Costa Rica: Asociación Costarricense de las Ciencias del Suelo. 
Alvarado A: Nutrición y fertilización de Tectona grandis Linn. f. In Nutrición y fertilización forestal en regiones tropicales A Alvarado \& J Raigosa 2012b, 313-340, San José, Costa Rica: Asociación Costarricense de las Ciencias del Suelo. Barker AV, Pilbeam DJ: Handbook of plant nutrition Boca Raton, FL, USA: CRC Press; 2006.

Bertsch F: La fertilidad de los suelos y su manejo 1998, San José, Costa Rica: Asociación Costarricense de la Ciencia del Suelo.

Binkley D: Forest nutrition management. New York, USA: Wiley-Interscience; 1986.

Binkley D, Stape JL, Ryan MG, Barnard HR, Fownes J: Age-related decline in forest ecosystem growth: an individual-tree, stand-structure hypothesis. Ecosystems 2002, 5:58-67.

De Camino R, Alfaro MM, Sage LFM: Teak (Tectona grandis) in Central America. Rome: Food and Agriculture Organization; 2002, (FAO Plantations Working Paper $F P / 19)$.

Drechsel P, Zech W: Foliar nutrient levels of broad-leaved tropical trees: a tabular review. Plant and Soil 1991, 131(1):29-46.

Evans J: Planted forests: uses, impacts and sustainability. Rome: $C A B$ International/FAO 2009.

Evans J, Turnbull JW: Plantation forestry in the Tropics. New York, USA: Oxford University Press; 2004

Fernández-Moya J, Murillo R, Portuguez E, Fallas JL, Ríos V, Kottman F, Verjans JM, Mata R, Alvarado A: Nutrient concentrations age dynamics of teak plantations in Central America (Tectona grandis L.f.) plantations in Central America. Forest Systems 2013, 22(1):123-133.

Fernández-Moya J, Alvarado A, Morales M, San Miguel-Ayanz A, MarchamaloSacristán M: Using multivariate analysis of soil fertility as a tool for forest fertilization planning. Nutrient Cycling in Agroecosystems 2014, 98(2):155-167. Fernández-Moya J, Murillo R, Portuguez E, Fallas JL, Ríos V, Kottman F, Verjans JM, Mata R, Alvarado A: Nutrient accumulation and export in teak (Tectona grandis L.f.) plantations in Central America. iForest - Biogeosciences and Forestry 2014, doi: 10.3832/ifor1089-007.

Fölster H, Khanna PK: Dynamics of nutrient supply in plantation soils. In Management of soil, nutrients and water in tropical plantation forests. Canberra, Australia: Australian Centre for International Agricultural Research;EKS Nambiar \& Brown AG 1997:339-379.

Food and Agriculture Organization (FAO): Global forest resources assessment 2010. 2010, Rome.

Forest Stewardship Council (FSC): Perspectivas sobre plantaciones: Desafío para el manejo de plantaciones. Bonn, Germany; 2004.

Fox TR: Sustained productivity in intensively managed forest plantations. Forest Ecology and Management 2000, 138:187-202.

Gholz HL, Lima WP: The ecophysiological basis for productivity in the tropics. In Management of soil, nutrients and water in tropical plantation forests. Canberra, Australia: Australian Centre for International Agricultural Research;EKS Nambiar \& AG Brown 1997:213-246.

Gower ST, McMurtrie RE, Murty D: Aboveground net primary production decline with stand age: potential causes. Tree 1996, 11(9):378-382. Holdridge LR: Life zone ecology. San José, Costa Rica: Tropical Science Center 1967.

Kollert W, Cherubini L: Teak resources and market assessment 2010. Rome: Food and Agriculture Organization 2012, (FAO Planted Forests and Trees Working Paper FP/47/E).

Kumar BM: Soil management in teak plantations. In Proceedings of the

International Training Programme "Innovations in the management of planted teak forests". Peechi, India: TEAKNET;K Jayaraman \& KV Bhat 2011:24-30.

Kumar JIN, Kumar RN, Kumar BR, Sajish PR: Quantification of nutrient content in the aboveground biomass of teak plantation in a tropical dry deciduous forest of Udaipur, India. Journal of Forest Sciences 2009, 55(6):251-256. Lehto T, Ruuhola T, Dell B: Boron in forest trees and forest ecosystems. Forest Ecology and Management 2010, 260:2053-2069.

McBratney AB, Mendonça Santos ML, Minasny B: On digital soil mapping. Geoderma 2003, 117:3-52

Mead DJ: Diagnosis of nutrient deficiencies in plantations. In Nutrition of plantation forests. London, UK: Academic Press;GD Bowen \& EKS Nambiar 1984:259-292.

Miller HG: Dynamics of nutrient cycling in plantation ecosystems. In Nutrition of plantation forests. London, UK: Academic Press;GD Bowen \& EKS Nambiar 1984:53-79.
Montero M: Factores de sitio que influyen en el crecimiento de Tectona grandis L.f. y. Bombacopsis quinata 1999, (Jacq.) Dugand, en Costa Rica. MSC Thesis, Universidad Austral de Chile / CATIE.

Montes C, Ojeda H, Barría B, Burgos P, Allen HL: Combining soil and environmental information to predict growth response to nitrogen fertilizer in adult stands of radiate pine in Chile. IUFRO Conference "Nutrient Dynamics of Planted Forests" Vancouver, Washington, USA; 2012.

Negi MS, Tandon VN, Rawat HS: Biomass and nutrient distribution in young teak (Tectona grandis Linn. f.) plantation in Tarai Region of Uttar Pradesh. Indian Forestry 1995, 121(6):455-464.

Nwoboshi LC: Growth and nutrient requirements in a teak plantation age series in Nigeria. II. Nutrient accumulation and minimum annual requirements. Forest Science 1984, 30(1):35-40.

Ortega RA, Santibáñez OA: Determination of management zones in corn (Zea mays L.) based on soil fertility. Computers and Electronic in Agriculture 2007, 58:49-59.

Pandey D, Brown C: Teak: a global overview. Unasylva 2000, 51(2):1-15.

Rennie PJ: The uptake of nutrients by mature forest growth. Plant and Soil 1955, 8(1):49-95.

Robert PC: Precision agriculture: a challenge for crop nutrition management. Plant and Soil 2002, 247:143-149.

Ryan MG, Binkley D, Fownes JH: Age-related decline in forest productivity: pattern and process. Advances in Ecological Research 1997, 27:213-262. Sadler EJ, Karlen DL: Aerial dry matter and nutrient accumulation comparisons among five soybean experiments. Communications in Soil Sciences and Plant Analysis 1995, 26(19\&20):3145-3163.

Totey N: Fertilizer management in forest plantations. In Non-traditional sectors for fertilizer use. New Delhi, India: Fertilizer Development and Consultation Organization;HLS Tandon 1992:107-128.

Worrel R, Hampson A: The influence of some forest operations on the sustainable management of forest soils - a review. Forestry 1997, 70(1):61-85.

doi:10.1186/1179-5395-44-S1-S6

Cite this article as: Fernández-Moya et al:: Forest nutrition and

fertilization in teak (Tectona grandis L.f.) plantations in Central America ${ }^{\dagger}$ New Zealand Journal of Forestry Science 2014 44(Suppl 1):S6.

\section{Submit your manuscript to a SpringerOpen ${ }^{\circ}$ journal and benefit from:}

- Convenient online submission

- Rigorous peer review

- Immediate publication on acceptance

- Open access: articles freely available online

- High visibility within the field

- Retaining the copyright to your article

Submit your next manuscript at $\boldsymbol{\Delta}$ springeropen.com 